\title{
Phenotypic and genotypic characterization of Staphylococcus aureus isolates in milk from flocks diagnosed with subclinical mastitis
}

\author{
A.R.E.O. Xavier ${ }^{1}$, A.C. Almeida ${ }^{2}$, C.N. Souza ${ }^{2}$, L.M.V Silva², A.X.A. Ruas ${ }^{2}$, \\ D.A. Sanglard ${ }^{3}$, A.F.M. Júnior ${ }^{1}$, A.M.E. Oliveira ${ }^{4}$ and M.A.S. Xavier ${ }^{1}$ \\ ${ }^{1}$ Laboratório de Bioprospecção e Recursos Genéticos, \\ Centro de Ciências Biológicas e da Saúde, \\ Universidade Estadual de Montes Claros, Montes Claros, MG, Brasil \\ ${ }^{2}$ Laboratório de Sanidade Animal, Centro de Pesquisa em Ciências Agrárias, \\ Instituto de Ciências Agrárias, Universidade Federal de Minas Gerais, \\ Montes Claros, MG, Brasil \\ ${ }^{3}$ Laboratório de Biotecnologia, Centro de Pesquisa em Ciências Agrárias, \\ Montes Claros, Instituto de Ciências Agrárias, \\ Universidade Federal de Minas Gerais, MG, Brasil \\ ${ }^{4}$ Instituto de Ciências Agrárias, Universidade Federal de Uberlândia, \\ Uberlândia, MG, Brasil \\ Corresponding author: A.R.E.O. Xavier \\ E-mail: ericsson_aerc@yahoo.com.br
}

Genet. Mol. Res. 16 (2): gmr16029709

Received April 24, 2017

Accepted May 22, 2017

Published June 29, 2017

DOI http://dx.doi.org/10.4238/gmr16029709

Copyright (C) 2017 The Authors. This is an open-access article distributed under the terms of the Creative Commons Attribution ShareAlike (CC BY-SA) 4.0 License.

ABSTRACT. The Staphylococcus aureus is the most common
isolated microorganism in ruminant animal species diagnostic with
clinical or subclinical mastitis. Dairy herds with these diseases
can transfer $S$. aureus into the milk supply, which can lead to food
poisoning in humans. The objective of this study was to evaluate the
profile of antimicrobial susceptibility, the presence of femA gene, the
genetic relationships among isolates of $S$. aureus obtained from milk

Genetics and Molecular Research 16 (2): gmr16029709 
originating from flocks diagnosed with subclinical mastitis in nine rural properties in the northern of Minas Gerais State. To this end, 498 samples of bovine milk tested positive for the California mastitis test (CMT) were subjected to morphological methods and biochemical patterns for microbiological presumptive identification of $S$. aureus. The PCR test with the genetic marker femA was used to confirm the species $S$. aureus. All the 26 isolates presumptively identified as $S$. aureus amplified a fragment of $132 \mathrm{bp}$ corresponding to the $\mathrm{fem} A$ gene. The profile of antimicrobial susceptibility was performed according to the disk-diffusion methodology and two isolates were susceptible to all the antibiotics tested. The drug multiresistence was found in $80.76 \%$ of the isolates. The determination of the genetic profile and the clonal relationship among the isolates was performed by the method of DNA RAPD-PCR polymorphism. The $S$. aureus isolates were divided into two groups with 26 distinct subgroups. The analysis of RAPD-PCR showed no genetic diversity among them, heterogeneous profile and absence of clonality.

Key words: Genetic diversity; femA gene; RAPD; Resistance; Antimicrobials; Staphylococcus aureus

\section{INTRODUCTION}

The bovine mastitis is one of the most common diseases occurring in dairy cattle and its main feature is the inflammation of the mammary glands (Viguier et al., 2009; Song et al., 2016). The disease occurs in two ways: clinical and subclinical mastitis. The clinical one has evident characteristics in its expression, but the subclinical mastitis requires complementary examinations, such as the California mastitis test (CMT) and somatic cell counts in milk (SCC) (Pantoja et al., 2009; Silva and Nogueira, 2010; Rall et al., 2014). The subclinical mastitis has special importance as it goes unnoticed and affects in a great extent the production's animal (Bhati et al., 2016). As a result of bovine mastitis, there are low production levels, poor quality and/or discard of milk that generate economic losses in the dairy cattle industry (Viguier et al., 2009; Song et al., 2016).

A wide variety of microbial agents may be involved with the etiology of bovine mastitis, however, Staphylococcus aureus is the most prevalent in intramammary infections being related to more than $80 \%$ of the cases (Pellegrino et al., 2011; Song et al., 2016). Although fungi and algae have been observed in cow milk diagnosed with clinical mastitis, $90 \%$ of isolates are represented by bacteria, including those belonging to the genera Staphylococcus, Streptococcus and coliforms (Ganda et al., 2016).

Prevention and treatment programs to mastitis include the use of antimicrobials in dairy cattle flocks in an attempt to eliminate the disease (Pellegrino et al., 2011; Silva et al., 2012; Teixeira et al., 2014). However, the indiscriminate use of antibiotics, which can lead to drug multiresistance and the risk of the presence of its residues in the milk, has turned mastitis an important disease to public health (Ganda et al., 2016). The correct identification of the mastitis pathogen is an important factor for the treatment and prophylaxis of this infection. DNA-based molecular typing methods are more efficient and have high sensitivity and

Genetics and Molecular Research 16 (2): gmr16029709 
specificity for the identification of microorganisms (Tel and Bozkaya, 2012; Rahman et al., 2016). The identification of $S$. aureus at the species level can be performed by PCR through detection of the fem $\mathrm{A}$ (factor essential for methicillin resistance) gene. This gene codes for a protein of $48-50 \mathrm{kDa}$, which is recognized as a specific factor and chromosomally coded in this pathogen, being involved in the structure of the bacterial cell wall (Rodrigues da Silva and Silva, 2005; Teixeira et al., 2014). S. aureus is well known for having resistance to antimicrobial agents, which may lead to complications for the treatment of their infections besides increasing the treatment costs. One of these resistances is coded by the mecA (methicilin resistance) gene, which confers resistance to all beta-lactamases including methicillin, oxacillin and cephalosporins (Nemeghaire et al., 2014).

Several molecular typing methods have been used in order to investigate the bovine mastitis epidemiology at the level of subspecies. They include methods of comparative typing based on standard electrophoretic bands, typing methods of libraries and genome sequencing. Among the typing methods based on fingerprint, PCR-RFLP, RAPD-PCR, ERIC-PCR, BOXPCR, and REP-PCR have been described as simple and quick techniques for taxonomic and epidemiological analyses of several species of the genus Staphylococcus (Bergonier et al., 2014; Idil and Bilkay, 2014; Rahman et al., 2016; Ławniczek-Wałczyk et al., 2017). Epidemiological molecular studies have contributed significantly to the understanding of the sources, routes of transmission and prognosis for many pathogens that cause bovine mastitis, as well as to understand the mechanisms of adaptation to the host and the causes of the disease (Supré et al., 2011; McMillan et al., 2016).

The objective of this study was to recognize the antimicrobial susceptibility profile of S. aureus obtained from bovine milk with subclinical mastitis, as well as to characterize the molecular and epidemiological profile of the isolates.

\section{MATERIAL AND METHODS}

\section{Bacterial isolates and profile of antimicrobial sensitivity}

Nine properties of rural producers in the municipalities of Janaúba (AG e NP), Icaraí de Minas (CC, GU and VA), Porteirinha (MU), Matias Cardoso (MC), Bocaiúva (TR), and São João da Lagoa (SL) in northern of Minas Gerais State were chosen, whose geographical location is shown in Figure 1.

The milk collection in these properties was performed from January to April 2016. In each animal, before milking, CMT for the diagnosis of subclinical mastitis was perfomed. The CMT test was performed in all the lactating dairy cows and from the 15th day postpartum, a commercial product was used, specific to the test, and each teat was classified as: negative $(-)$, mild reaction $(+)$, moderate $(++)$, and severe $(+++)$, in accordance with the intensity of the gel. The positive milk samples for CMT were selected and sent to the Laboratory of Animal Health from the Institute of Agricultural Sciences of the Federal University of Minas Gerais for microbiological analysis. The genus-level identification of isolates was obtained by microbiological standard analyses, including biochemical and enzymatic tests complying with the Clinical Laboratory Standard Institute (CLSI) standardized in the Microbiology Laboratory (Gram staining, catalase test, coagulase test, and the DNAse test). The susceptibility to several classes of antibiotics was determined by the disk diffusion method according to CLSI (Wayne, 2016) using the following antimicrobials (Laborclin): $10 \mu \mathrm{g}$ gentamicin (GEN), 300

Genetics and Molecular Research 16 (2): gmr16029709 
$\mu \mathrm{g}$ nitrofurantoin (NIT), $10 \mu \mathrm{g}$ amikacin (AMI), $10 \mu \mathrm{g}$ amoxicillin (AMO), 10U penicillin $\mathrm{G}(\mathrm{PEN}), 30 \mu \mathrm{g}$ cefoxitin (CFO), $1 \mu \mathrm{g}$ oxacillin (OXA), $5 \mu \mathrm{g}$ ciprofloxacin (CIP), $10 \mu \mathrm{g}$ ampicillin (AMP), and $30 \mu \mathrm{g}$ cephalothin (CFL). A standard strain of S. aureus ATCC 25923 was used as a positive control. The S. aureus isolates were stored at $-20^{\circ} \mathrm{C}$ in the BHI medium (Prodimol Biotechnology) containing 20\% glycerol.

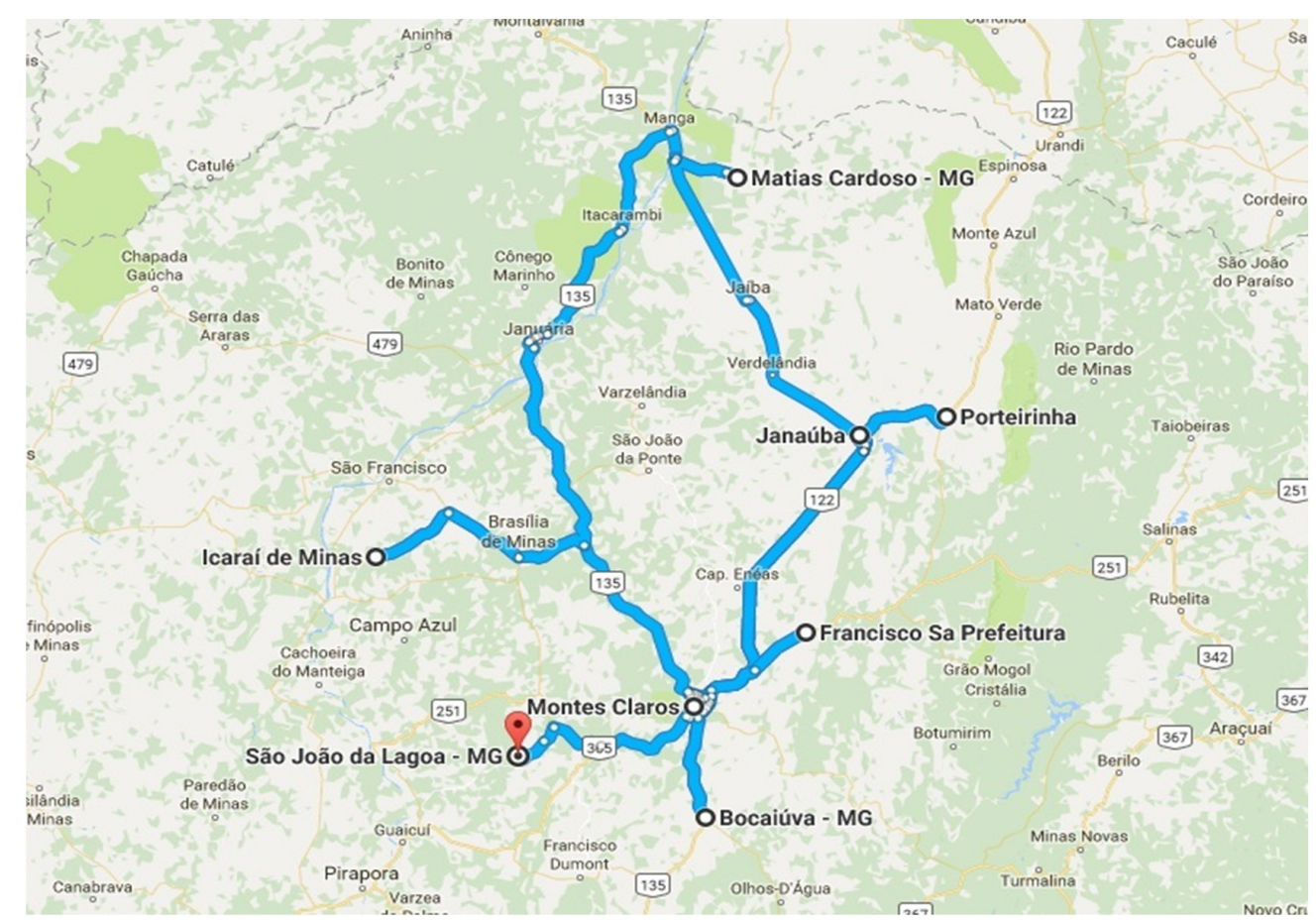

Figure 1. Political map and geographic coordinates of rural properties where Staphylococcus aureus were isolated in milk samples from bovines diagnosed with subclinical mastitis. Matias Cardoso (14 $\left.51^{\prime} 20^{\prime \prime} \mathrm{S}, 4^{\circ} 54^{\prime} 50^{\prime \prime} \mathrm{W}\right)$

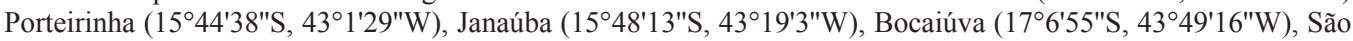

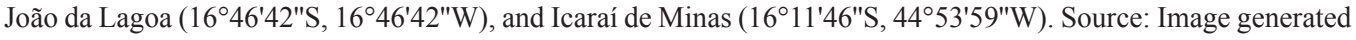
by Google Maps.

\section{DNA extraction and PCR analysis for the detection of the fem $A$ gene}

The cryopreserved isolates of $S$. aureus were reactivated by sowing in the BHI medium (Prodimol Biotechnology) and incubated at $37^{\circ} \mathrm{C}$ for $24 \mathrm{~h}$. The grown bacterial cultures were sent to the Laboratory of Biotechnology of Federal University of Minas Gerais, where they were subjected to DNA extraction using the digestion method by K- proteinase followed by phenol-chloroform (Barea et al., 2004) with some modifications. A volume of $1.5 \mathrm{~mL}$ of each culture of $S$. aureus was centrifuged at $5000 \mathrm{rpm}$ for $3 \mathrm{~min}$. The supernatant was discarded and the bacterial cell pellet ressuspended in $400 \mu \mathrm{L}$ buffer of digestion $(0.9 \% \mathrm{NaCl}, 0.2 \mathrm{M}$ EDTA and $20 \mathrm{mg} / \mathrm{mL}$ proteinase K). It was added $40 \mu \mathrm{L}$ SDS at $20 \%$ and the samples incubated in a water bath at $60^{\circ} \mathrm{C}$ for $10 \mathrm{~min}$ and then cooled at room temperature. The DNA precipitation

Genetics and Molecular Research 16 (2): gmr16029709 
was performed with $1 \mathrm{~V}$ of phenol and $1 \mathrm{~V}$ of isoamyl alcohol: chloroform (1:24), followed by centrifugation, for $5 \mathrm{~min}$, at 10,000 $\mathrm{rpm}$. The aqueous phase was transferred to new tube, where $2 \mathrm{~V}$ of $100 \%$ ice-cold ethanol and $0.1 \mathrm{M} \mathrm{NaCl}$ were added. The samples were incubated for $10 \mathrm{~min}$ on ice and then centrifuged at 14,000 rpm for $10 \mathrm{~min}$. The supernatant was discarded and the sedimented DNA after drying process was resuspended in preserving buffer $(10 \mathrm{mM}$, $\mathrm{pH}$ 8.0 TRIS, $5 \mathrm{mM}$ EDTA) and stored at $-20^{\circ} \mathrm{C}$. The integrity and quantification of extracted DNAs were checked by agarose gel electrophoresis at $1.0 \%$. This material was used in the PCR and RAPD-PCR performed in the Bioprospecting and Genetic Resources Laboratory in the State University of Montes Claros. All the primers used in this study were synthesized by Integrated DNA Technology, USA.

Genus-level identification of $S$. aureus strains was performed by tracking the presence of the femA through PCR technique. The pair of primers FemA15'AAAAAAGCACATAACAAGCG3' and FemA2-5'GATAAAGAAGAACCAGCAG3' were used and the PCR conditions according to Teixeira et al. (2014). The reactions were carried out in a mix containing $1 \mathrm{X}$ Taq buffer from the Kappa kit PCR, $\mathrm{MgCl}_{2}(2.5 \mathrm{mM})$, deoxynucleotides $(1 \mu \mathrm{M})$, Taq Polymerase Kappa (0.5 U), $1.25 \mu \mathrm{M}$ of each primer, and $50 \mathrm{ng}$ bacterial DNA in a final total reaction volume of $25 \mu \mathrm{L}$. The 132-base pair expected amplicons were visualized on $1.5 \%$ agarose gel stained with ethidium bromide and photographed and documented.

\section{RAPD-PCR and statistical analysis}

The characterization of the genetic profile and the clonal relationship among the $S$. aureus isolates were performed using the RAPD-PCR technique. For the RAPD-PCR, oligonucleotide S232 was used and the PCR conditions described in the literature for the polymorphism analysis intra- and interspecies of $S$. aureus (Idil and Bilkay, 2014). The reactions were carried out in a mix containing $1 \mathrm{X}$ Taq buffer from the Kappa kit PCR, $\mathrm{MgCl}_{2}(2.5 \mathrm{mM})$, deoxy nucleotides $(1 \mu \mathrm{M})$, Taq Polymerase Kappa $(0.5 \mathrm{U}), 1 \mu \mathrm{M}$ of each primer and $250 \mathrm{ng}$ of bacterial DNA in a final total reaction volume of $25 \mu \mathrm{L}$. The amplicons were visualized on $1.5 \%$ agarose gel stained with ethidium bromide and photographed and documented. The analysis of the profiles of DNAs amplification obtained through RAPD-PCR was performed by visual inspection of two observers and transformed into binary data in a matrix, according to the presence (1) or absence (0) of bands. To assess the genetic relationship among the isolates the matrix was subjected to grouping analysis by the nearest neighbor method (UPGMA or unweight pair-group method with arithmetic mean) based on the Pearson correlation coefficient for automatic generation of the dendrogram using the statistical program 2008 Statistical Package (MVSP) version 3.12h (GeoMem, Barrow in Furness, United Kindgom).

\section{Ethical aspects}

This study was performed following ethical standards approved by the Ethics and Animal Experimentation Committe from the Federal University of Minas Gerais, under Protocol No. 145/2013.

\section{RESULTS AND DISCUSSION}

In this study, 26 isolates from 498 samples of bovine milk tested positive for the CMT,

Genetics and Molecular Research 16 (2): gmr16029709 
originating from 9 different rural properties in northern Minas Gerais were initially identified as $S$. aureus by standard morphological and biochemical methods. The isolate identification was confirmed through the femA gene PCR of $S$. aureus. All the $S$. aureus $(\mathrm{N}=26)$ exhibited a 132-base pair amplicon specific species (Figure 2) corresponding to the genetic marker femA.

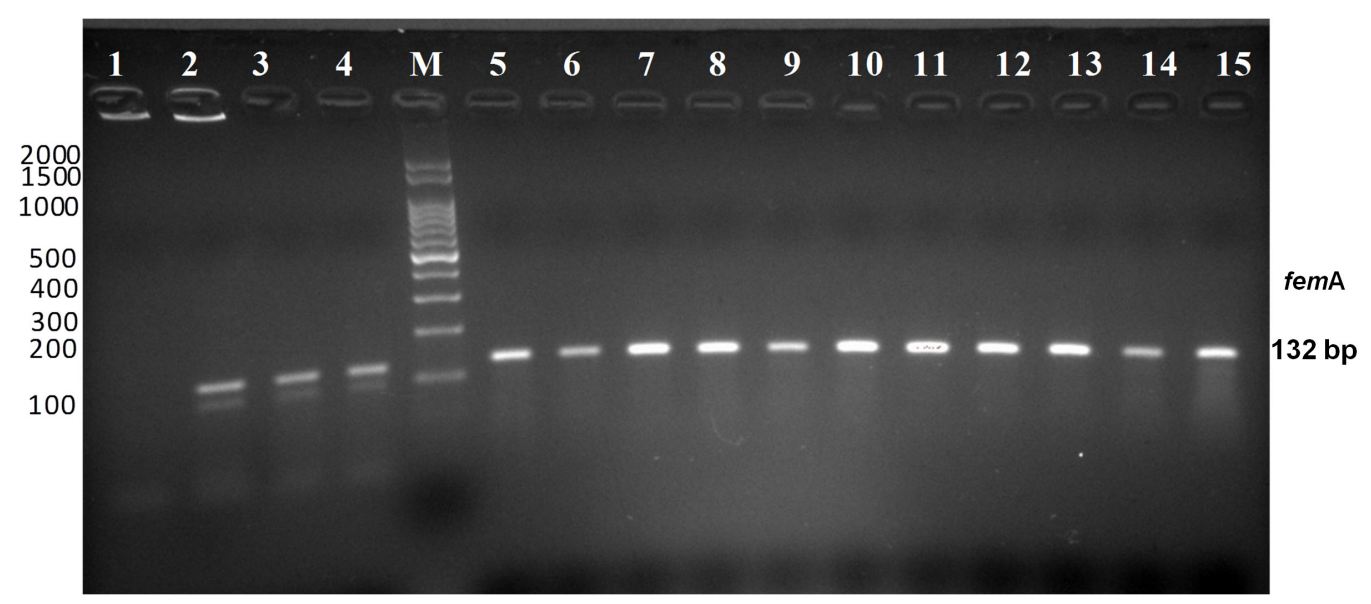

Figure 2. PCR for the detection of the femA gene among Staphylococcus aureus isolated from bovine milk with subclinical mastitis. Lane 1: negative control (absence of DNA). Lane 2: positive control (S. aureus ATCC 25923 strain). Lanes 3, 4, 5, 6, and 7: isolates 1 to 5 from the rural propriety NP (municipality of Janaúba). Lane 5: marker of molecular weight of 100 base pairs DNA (Ludwig). Lanes 8 to 15: isolates 1 to 8 from the rural propriety (municipality of Bocaiúva). The size of the 100-base pair marker is indicated on the left. The expected amplified fragment of 132-base pairs of the corresponding fem A gene is indicated on the right in the gel.

This marker has been described in the literature as a signature sequence for genotyping of S. aureus isolates (Rodrigues da Silva and Silva, 2005; Teixeira et al., 2014; Oliveira et al., 2016), which corroborates the results of the genus and species of microorganisms identified in this study as $S$. aureus.

The antimicrobial susceptibility test showed that $S$. aureus isolated from cases of bovine subclinical mastitis in Northern rural properties from Minas Gerais exhibited varying degrees of antimicrobial resistance (Table 1).

They were resistant to amikacin (2.60\%), amoxicillin (76.03\%), ampicillin (80.76\%), cephalothin (2.60\%), cefoxitin (15.38\%), penicillin (92.30\%), and oxacillin (2.6\%). The isolates NP4 and TR5 showed sensitivity to all antibiotics to which they were tested, however, the drug multiresistance was found in $80.76 \%$ (21/26) of the isolates (Table 1). Similar results regarding the percentage of $S$. aureus isolates multiresistant to drugs were found in a study by Silva et al. (2012).

$S$. aureus isolated from animals with clinical and subclinical mastitis exhibit high rates of resistance to beta-lactam antibiotics (Kalmus et al., 2011; El Behiry et al., 2012; Silva et al., 2012; Jagielski et al., 2014; Schmidt et al., 2015). A considerable rate of simultaneous resistance to beta-lactamases amoxicillin, ampicillin and penicillin was found in $69.03 \%$ $(18 / 26)$ of $S$. aureus isolates in this study (Table 1). Silva et al. (2012) analyzing the sensitivity profile in vitro of $S$. aureus isolates of bovine subclinical mastitis found a simultaneous rate of resistance to penicillin and ampicillin of $66 \%$. These authors suggested that the same resistance mechanism is responsible for the inactivation of the tested drugs. 
Table 1. Phenotypic characterization of antibiotic resistance, femA gene tracking and genetic profile analysis of the 26 Staphylococcus aureus isolated from bovine milk with subclinical mastitis in different rural properties in Northern Minas Gerais.

\begin{tabular}{|c|c|c|c|c|c|c|}
\hline \multirow[t]{2}{*}{ Isolates } & \multirow[t]{2}{*}{ Isolation date } & \multirow[t]{2}{*}{ Municipality in Minas Gerais } & \multirow[t]{2}{*}{ Antimicrobials resistance profile ${ }^{\mathrm{a}}$} & \multirow[t]{2}{*}{ femA gene } & \multicolumn{2}{|c|}{ Genetic Profile - RAPD-PCR } \\
\hline & & & & & Group & Genotype \\
\hline NP1 & $02 / 26 / 2016$ & Janaúba & PEN, CFO, AMP & + & II & $\mathrm{D}$ \\
\hline NP2 & $02 / 26 / 2016$ & Janaúba & PEN & + & II & $\mathrm{C}$ \\
\hline NP3 & $02 / 26 / 2016$ & Janaúba & AMO, PEN, CFO, GEN, & + & II & B \\
\hline NP4 & $02 / 26 / 2016$ & Janaúba & $\mathrm{S}$ & + & I & $\mathrm{V}$ \\
\hline NP5 & $02 / 26 / 2016$ & Janaúba & AMP & + & II & A \\
\hline TR1 & $4 / 19 / 2016$ & Bocaiuva & AMO, PEN, AMP & + & $\mathrm{I}$ & $\mathrm{R}$ \\
\hline TR2 & $4 / 19 / 2016$ & Bocaiuva & AMO, PEN, AMP & + & $\mathrm{I}$ & $\mathrm{D}$ \\
\hline TR3 & $4 / 19 / 2016$ & Bocaiuva & AMO, PEN, AMP & + & $\mathrm{I}$ & $\mathrm{C}$ \\
\hline TR4 & $4 / 19 / 2016$ & Bocaiuva & AMO, PEN, AMP & + & $\mathrm{I}$ & $\mathrm{M}$ \\
\hline TR5 & $4 / 19 / 2016$ & Bocaiuva & $\mathrm{S}$ & + & I & $\mathrm{K}$ \\
\hline TR6 & $4 / 19 / 2016$ & Bocaiuva & PEN, AMP & + & I & $\mathrm{L}$ \\
\hline TR7 & $4 / 19 / 2016$ & Bocaiuva & AMO, PEN, AMP & + & I & $\mathrm{J}$ \\
\hline TR8 & $4 / 19 / 2016$ & Bocaiuva & AMO, PEN, AMP & + & I & I \\
\hline MC1 & $4 / 20 / 2016$ & Matias Cardoso & AMO, PEN, AMP & + & $\mathrm{I}$ & $\mathrm{H}$ \\
\hline $\mathrm{MC} 2$ & $4 / 20 / 2016$ & Matias Cardoso & AMO, PEN, AMP & + & I & G \\
\hline MC3 & $4 / 20 / 2016$ & Matias Cardoso & PEN & + & I & $\mathrm{F}$ \\
\hline MC4 & $4 / 20 / 2016$ & Matias Cardoso & AMO, PEN, AMP & + & I & $\mathrm{Q}$ \\
\hline GU1 & $1 / 29 / 2016$ & Icaraí de Minas & AMO, PEN, AMP & + & I & B \\
\hline $\mathrm{CC} 1$ & $1 / 30 / 2016$ & Icaraí de Minas & AMO, PEN, AMP, AMI & + & I & A \\
\hline $\mathrm{CC} 2$ & $1 / 30 / 2016$ & Icaraí de Minas & AMO, PEN, AMP & + & I & $\mathrm{U}$ \\
\hline AG1 & $2 / 24 / 2016$ & Janaúba & AMO, PEN, CFO, AMP & + & I & $\mathrm{T}$ \\
\hline MU1 & $1 / 7 / 2016$ & Muganga & AMO, PEN, AMP & + & I & $\mathrm{O}$ \\
\hline MU2 & $1 / 7 / 2016$ & Muganga & AMO, PEN, AMP & + & I & $\mathrm{P}$ \\
\hline MU3 & $1 / 7 / 2016$ & Muganga & AMO, PEN, AMP & + & I & $\mathrm{N}$ \\
\hline SL1 & $1 / 12 / 2016$ & Bocaiuva & AMO, PEN, CFO, OXA, AMP, CFL & + & I & E \\
\hline VA1 & $1 / 28 / 2016$ & Icaraí de Minas & AMO, PEN, AMP & + & I & $\mathrm{S}$ \\
\hline
\end{tabular}

${ }^{\mathrm{a}} \mathrm{AMO}=$ amoxicillin; $\mathrm{AMP}=$ ampicillin $; \mathrm{CFL}=$ cephaloxitin; $\mathrm{CFO}=$ cefoxitin; $\mathrm{PEN}=$ penicillin; $\mathrm{OXA}=$ oxacillin; $\mathrm{S}=$ sensitive to all the tested antibiotic. More details in materials and methods.

Animals chronically infected are reservoires of penicillin resistant $S$. aureus and disseminate this phenotype. This dissemination associated with low rate of microbiological cure of mastitis caused by this microorganism allows animals chronically infected remain in the flock and spread resistant strains to other animals (Taponen et al., 2003; Barkema et al., 2006; Silva et al., 2012).

The sensitivity determination to in vitro antimicrobial agents may not reflect the real pathogen profile when in real contact with the drug (Silva et al., 2012). However, the determination of the $S$. aureus susceptibility profile from bovine mastitis before antibiotics can be helpful in choosing the most adequate drug for the treatment of the disease. In addition, the recognition of effective mechanisms for the disease control could be established (Wang et al., 2016).

In farms, pathogenic strains of microorganisms may originate from a variety of sources, including the animal itself. These strains can easily pass from one source to another through different routes of transmission, which include: contact between animals, stalls, milking equipment, and the milkers' hands (McMillan et al., 2016). Genotypic methods may be employed to obtain information regarding the potential infection sources and routes of diseases transmission. The random amplification of polymorphic DNA analysis (RAPD) is a technique that allows to analyze the genetic diversity among $S$. aureus isolates (Idil and Bilkay, 2014; Rahman et al., 2016; Wang et al., 2016). In this study, the genotypic analysis of 26 isolates carrying the femA gene employing the RAPD technique produced 16 distinct fragments (Figure 3).

Genetics and Molecular Research 16 (2): gmr16029709 


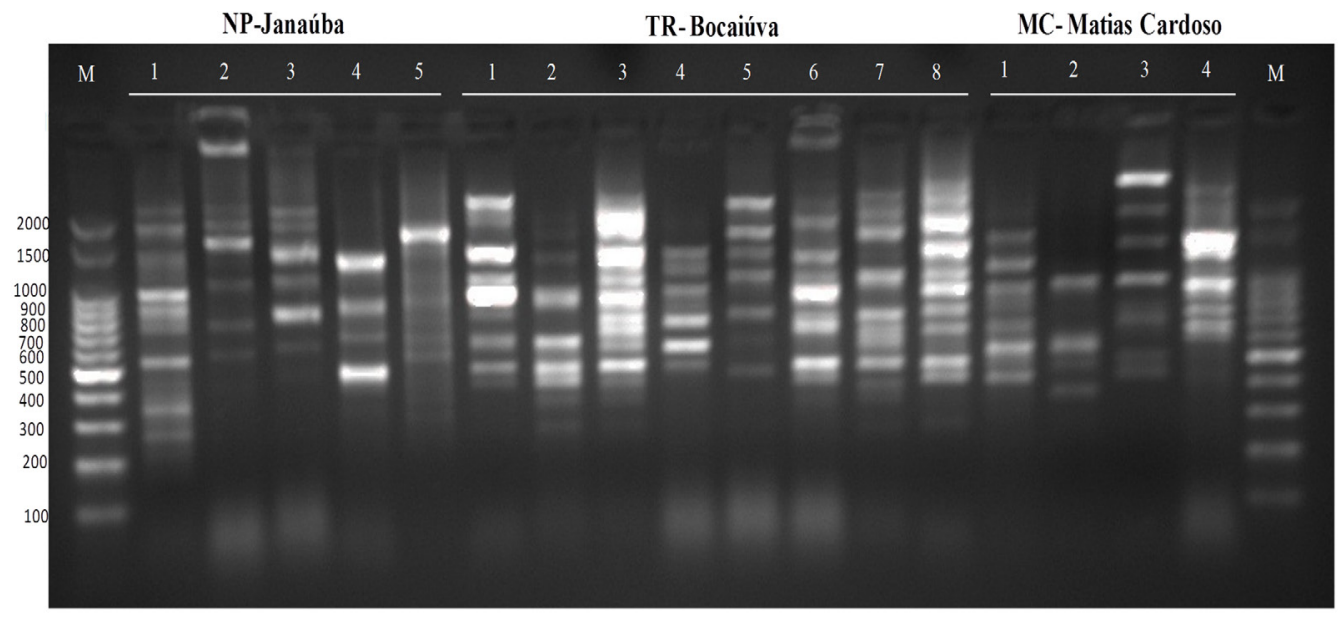

Figure 3. RAPD-PCR for the genetic profile determination of Staphylococcus aureus isolated from bovine milk in different proprieties of Northern Minas Gerais. Lane M: Marker of molecular weight of 100-base pairs DNA (Ludwig). Nucleus rural propriety: NP - municipality of Janaúba: isolates NP1 to NP5. TR - municipality of Bocaiúva: isolates TR1 to TR8. MC - municipality of Matias Cardoso isolates MC1 to MC4.

For band-sharing analysis, the bands in a range between 250 to 3000 base pairs were considered. The binary matrix made by visual observation on the presence or absence of these bands further submitted to the UPGMA analysis based on Pearson's coefficient generated a dendrogram of genetic relationships among S. aureus isolates (Figure 4).

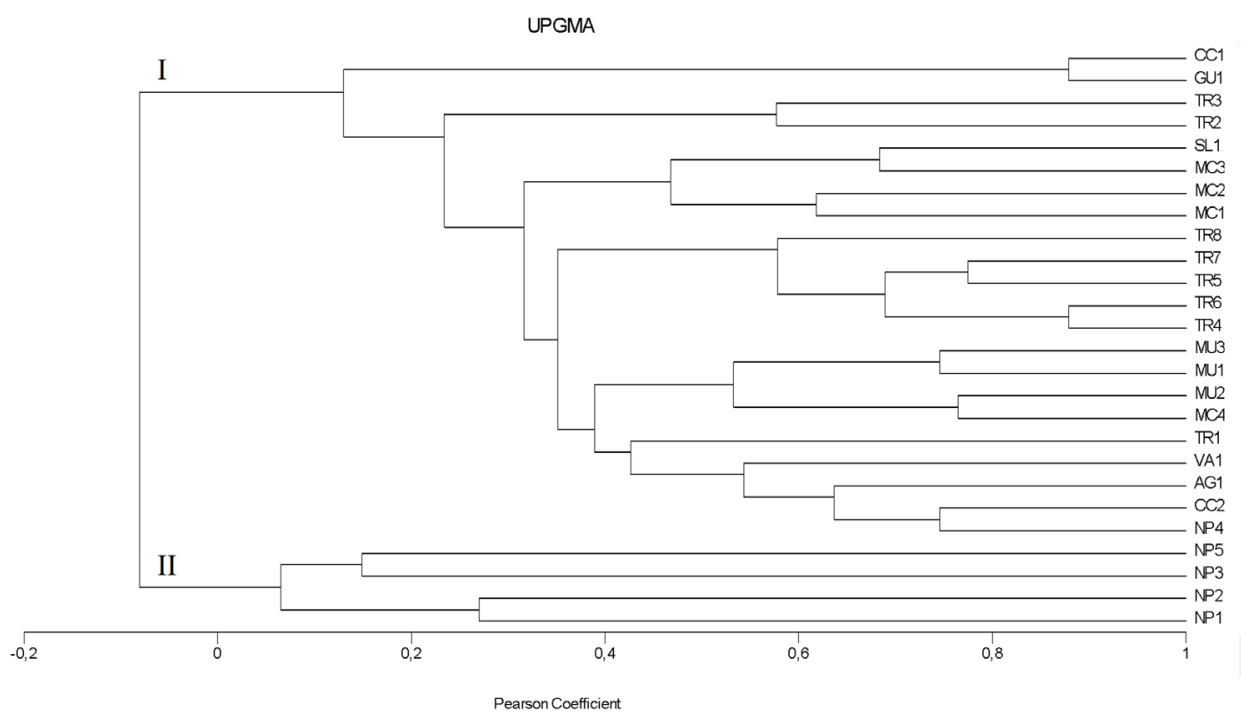

Figure 4. Dendrogram of genetic relationships of Staphylococcus aureus $(\mathrm{N}=26)$ isolated from bovine milk of with subclinical mastitis obtained by RAPD-PCR. The 26 isolates distributed into 2 groups (I and II) according to UPGMA analysis based on Pearson's coefficient.

Genetics and Molecular Research 16 (2): gmr16029709 
These isolates were grouped into two different groups of which $84.61 \%(22 / 26)$ profile of group I and 15.39\% (04/26) of Group II. Still according to the Pearson's correlation coefficient, it was possible to determine 26 different genotypes (IA to IU and IIA to IID), which showed a substantial variation of $S$. aureus genotypes not only among isolates from different rural properties, but also from those isolated in the same flock. (Figure 4 and Table 1). Wang et al. (2016), when analyzing RAPD polymorphism of $S$. aureus isolates recovered from cows with mastitis in China, obtained similar results to this study.

No clonality was verified among the $26 \mathrm{~S}$. aureus isolates carrying the femA gene. Profiles with Pearson's coefficient of 0.87 were found among strains of $S$. aureus isolated from flocks of the same rural property [clone IM (isolate TR4) and clone IL (isolate TR6)], as well as from rural properties, but located in the same municipality [clone IA (isolate CC1) and clone IB (isolate GU1)] (Figure 4 and Table 1). The bands sharing analysis among these isolates revealed the presence or absence of 1 or 3 bands in disagreement, which leads the authors to hypothesize possible mutation among the isolates. Carvalho et al. (2016) analyzing the genetic profile of nosocomial isolates of Acinetobacter baumanni through DNA polymorphism analysis by ERIC-PCR also suggested the same hypothesis for isolates with high genetic similarity.

Two isolates originated from different rural proprieties and municipalities (Janaúba and Bocaiuva) sensitive to all the tested antibiotics [NP4 (clone (I-V) and TR5 (clone I-K)] showed low similarity among themselves, with Pearson's coefficient of 0.35 (Figure 4 and Table 1). However, the comparison of the genetic relationship (Pearson's coefficient equal to 0.75 ) between the isolate TR5 sensitive to the tested antibiotics (clone I-K) and the multi-resistant TR-7 isolate (clone I-J) originated from the same rural property revealed the absence of correlation between the phenotypic susceptibility profile to antibiotics and the characterization of the genetic profile through RAPD-based polymorphism analysis for these isolates.

Idil and Biklay (2014) evaluated the use of the RAPD-PCR technique for clonality determination among nosocomial $S$. aureus isolates resistant to methicillin. According to their findings the combination of more than a RAPD primer can provide a greater power of discrimination among isolates of this species. In this study, we used the oligonucleotide S232 designed by Idil and Biklay (2014). Despite of the different origin and non-resistance to methicillin, the band profile obtained with the RAPD-PCR was similar to those authors. The combination of one or more RAPD primers could produce results with different similarity profiles. Nevertheless, it was possible to evidence it as a useful tool for future epidemiological studies using a higher number of samples to be isolated in herds in the studied region. It is possible to conclude that the femA species-specific for $S$. aureus was efficient for genotypic confirmation of isolates identified by standard microbiological analyses in this study. The antimicrobial susceptibility test displayed varying resistance degrees among the isolates. Nonetheless, it was considerable the simulateneous resistance rate to beta-lactams. There was a wide variation in the genotypes of $S$. aureus isolates, not only among those isolated from different rural properties, but also in the same flock. This wide genomic variation added to resistance to antimicrobials herein tested is a reason for concern about animal public health in the Minas Gerais regions where the microorganisms were isolated. The knowledge on the $S$. aureus genetic diversity and the antimicrobial resistance profile of dairy breeds may be useful as a tool for decision making in the implementation of control measures and prevention of clinical mastitis and or subclinical in milking environments.

Genetics and Molecular Research 16 (2): gmr16029709 


\section{Conflicts of interest}

The authors declare no conflict of interests.

\section{ACKNOWLEDGEMENTS}

Research supported by Conselho Nacional de Desenvolvimento Científico e Tecnológico (CNPq), Fundação de Amparo à Pesquisa do Estado de Minas Gerais (Fapemig) (\#APQ-01786-13), and the Dean's Office for Research studies of UFMG.

\section{REFERENCES}

Barea JA, Pardini MIMC and Gushiken T (2004). Extração de DNA de materiais de arquivo e fontes escassas para utilização em reação de polimerização em cadeia (PCR). Rev. Bras. Hematol. Hemoter. 26: 274-281 https://doi. org $/ 10.1590 / \mathrm{S} 1516-84842004000400008$.

Barkema HW, Schukken YH and Zadoks RN (2006). Invited Review: The role of cow, pathogen, and treatment regimen in the therapeutic success of bovine Staphylococcus aureus mastitis. J. Dairy Sci. 89: 1877-1895 https://doi.org/10.3168/ jds.S0022-0302(06)72256-1.

Bergonier D, Sobral D, Feßler AT, Jacquet E, et al. (2014). Staphylococcus aureus from 152 cases of bovine, ovine and caprine mastitis investigated by Multiple-locus variable number of tandem repeat analysis (MLVA). Vet. Res. (Faisalabad) 45: 97-104 https://doi.org/10.1186/s13567-014-0097-4.

Bhati T, Nathawat P, Sharma SK, Yadav R, et al. (2016). Polymorphism in spa gene of Staphylococcus aureus from bovine subclinical mastitis. Vet. World 9: 421-424 https://doi.org/10.14202/vetworld.2016.421-424.

Carvalho AA, Cardoso LL, Nogueira HS, Menezes EV, et al. (2016). Characterization and molecular epidemiology of extensively prevalent nosocomial isolates of drug-resistant Acinetobacter spp. Genet. Mol. Res. 15: gmr.15038608. http://dx.doi.org/10.4238/gmr.15038608

El Behiry A, Schlenker G, Szabo I and Roesler U (2012). In vitro susceptibility of Staphylococcus aureus strains isolated from cows with subclinical mastitis to different antimicrobial agents. J. Vet. Sci. 13: 153-161 https://doi.org/10.4142/ jvs.2012.13.2.153.

Ganda EK, Bisinotto RS, Decter DH and Bicalho RC (2016). Evaluation of an on-farm culture system (accumast) for fast identification of milk pathogens associated with clinical mastitis in dairy cows. PLoS One 11: e0155314 https://doi. org/10.1371/journal.pone.0155314.

Idil $\mathrm{N}$ and Bilkay IS (2014). Application of RAPD-PCR for determining the clonality of methicillin resistant Staphylococcus aureus isolated from different hospitals. Braz. Arch. Biol. Technol. 57: 548-553 https://doi.org/10.1590/S1516$\underline{8913201402116}$

Jagielski T, Puacz E, Lisowski A, Siedlecki P, et al. (2014). Short communication: Antimicrobial susceptibility profiling and genotyping of Staphylococcus aureus isolates from bovine mastitis in Poland. J. Dairy Sci. 97: 6122-6128 https:// doi.org/10.3168/jds.2014-8321.

Kalmus P, Aasmäe B, Kärssin A, Orro T, et al. (2011). Udder pathogens and their resistance to antimicrobial agents in dairy cows in Estonia. Acta Vet. Scand. 53: 4 https://doi.org/10.1186/1751-0147-53-4.

Lawniczek-Wałczyk A, Gołofit-Szymczak M, Cyprowski M, Stobnicka A, et al. (2017). Monitoring of bacterial pathogens at workplaces in power plant using biochemical and molecular methods. Int. Arch. Occup. Environ. Health 90: 285295 https://doi.org/10.1007/s00420-017-1197-z.

McMillan K, Moore SC, McAuley CM, Fegan N, et al. (2016). Characterization of Staphylococcus aureus isolates from raw milk sources in Victoria, Australia. BMC Microbiol. 16: 169-180 https://doi.org/10.1186/s12866-016-0789-1.

Nemeghaire S, Argudín MA, Haesebrouck F and Butaye P (2014). Epidemiology and molecular characterization of methicillin-resistant Staphylococcus aureus nasal carriage isolates from bovines. BMC Vet. Res. 10: 153-161 https:// doi.org/10.1186/1746-6148-10-153.

Oliveira SP, Xavier AREO, Souza CN, Cunha GSP, et al. (2016). Identificação genotípica de Staphylococcus aureus multiresistentes a drogas isolados de animais de produção. Cad. Ciênc. Agrá. 8: 45-51.

Pantoja JC, Hulland C and Ruegg PL (2009). Somatic cell count status across the dry period as a risk factor for the development of clinical mastitis in the subsequent lactation. J. Dairy Sci. 92: 139-148 https://doi.org/10.3168/ jds.2008-1477.

Genetics and Molecular Research 16 (2): gmr16029709 
Pellegrino MS, Frola ID, Odierno LM and Bogni CI (2011). Mastitis bovina: resistencia a antibióticos de cepas de Staphylococcus aureus asiladas de leche. REDVET. Rev. Electrón. Vet. 12: 1-14.

Rahman MM, Hunter HN, Prova S, Verma V, et al. (2016). The Staphylococcus aureus methicillin resistance factor fmtA is a D-amino esterase that acts on teichoic acids. MBio 7: e02070-e15 https://doi.org/10.1128/mBio.02070-15.

Rall VL, Miranda ES, Castilho IG, Camargo CH, et al. (2014). Diversity of Staphylococcus species and prevalence of enterotoxin genes isolated from milk of healthy cows and cows with subclinical mastitis. J. Dairy Sci. 97: 829-837 https://doi.org/10.3168/jds.2013-7226.

Schmidt T, Kock MM and Ehlers MM (2015). Diversity and antimicrobial susceptibility profiling of staphylococci isolated from bovine mastitis cases and close human contacts. J. Dairy Sci. 98: 6256-6269 https://doi.org/10.3168/jds.20159715.

Rodrigues da Silva E and da Silva N (2005). Coagulase gene typing of Staphylococcus aureus isolated from cows with mastitis in southeastern Brazil. Can. J. Vet. Res. 69: 260-264.

Silva ER, Pereira AMG, Moraes WS, Santoro KR, et al. (2012). Perfil de sensibilidade antimicrobiana in vitro de Staphylococcus aureus isolado de mastite subclínica bovina. Rev. Bras. Saúde Prod. Anim. 13: 701-711 https://doi. org/10.1590/S1519-99402012000300010.

Silva MVM and Nogueira JL (2010). Mastite: controle e profilaxia no rebanho bovino. Rev. Cient. Elet. Med. Vet. 15: 1-13.

Song M, He Y, Zhou H, Zhang Y, et al. (2016). Combined analysis of DNA methylome and transcriptome reveal novel candidate genes with susceptibility to bovine Staphylococcus aureus subclinical mastitis. Sci. Rep. 6: 29390 https:// doi.org/10.1038/srep29390.

Supré K, Haesebrouck F, Zadoks RN, Vaneechoutte M, et al. (2011). Some coagulase-negative Staphylococcus species affect udder health more than others. J. Dairy Sci. 94: 2329-2340 https://doi.org/10.3168/jds.2010-3741.

Taponen S, Jantunen A, Pyörälä E and Pyörälä S (2003). Efficacy of targeted 5-day combined parenteral and intramammary treatment of clinical mastitis caused by penicillin-susceptible or penicillin-resistant Staphylococcus aureus. Acta Vet. Scand. 44: 53-62. https://doi.org/10.1186/1751-0147-44-53

Teixeira JP, Silva N, Fonseca LM and Costa GM (2014). Uso de PCR Duplex para detecção dos genes femA e mecA e determinação da concentração inibitória mínima (CIM) em Staphylococcus aureus isolados de leite cru. Rev. Inst. Adolfo Lutz 73: 272-279 10.18241/0073-98552014731615.

Tel OY and Bozkaya F (2012). Identifying the Bacteria Causing Ovine Gangrenous Mastitis and Detection of Staphylococcus aureus in Gangrenous Milk by PCR. Kafkas Univ. Vet. Fak. Derg. 18: 401-406 10.9775/kvfd.2011.5556.

Viguier C, Arora S, Gilmartin N, Welbeck K, et al. (2009). Mastitis detection: current trends and future perspectives. Trends Biotechnol. 27: 486-493 https://doi.org/10.1016/j.tibtech.2009.05.004.

Wang D, Zhang L, Zhou X, He Y, et al. (2016). Antimicrobial susceptibility, virulence genes, and randomly amplified polymorphic DNA analysis of Staphylococcus aureus recovered from bovine mastitis in Ningxia, China. J. Dairy Sci. 99: 9560-9569 https://doi.org/10.3168/jds.2016-11625.

Wayne PA (2016). Performance standards for antimicrobial susceptibility testing. Clinical and Laboratory Standards Institute (CLSI). 26th informational supplement (CLSI document M100S).

Genetics and Molecular Research 16 (2): gmr16029709 